TITLE:

\title{
Morphology and Systematics of the ostracod Euconchoecia (Myodocopa: Halocyprididae) from the North-Western Pacific
}

\section{$\operatorname{AUTHOR}(\mathrm{S}):$}

Chavtur, Vladimir G.

\section{CITATION:}

Chavtur, Vladimir G.. Morphology and Systematics of the ostracod Euconchoecia

(Myodocopa: Halocyprididae) from the North-Western Pacific. Publications of the Seto Marine Biological Laboratory 2014, 42: 14-41

\section{ISSUE DATE:}

2014-04-10

URL:

http://hdl.handle.net/2433/185698

RIGHT: 


\title{
Morphology and Systematics of the ostracod Euconchoecia (Myodocopa: Halocyprididae) from the North-Western Pacific
}

\author{
VLADIMIR G. CHAVTUR \\ A.V. Zhirmunsky Institute of Marine Biology, Far East Branch, Russian Academy of Sciences, \\ Vladivostok 690041, Russia \\ Far Eastern Federal University, Vladivostok 690050, Russia \\ E-mail: vchavtur@gmail.com
}

\begin{abstract}
The North-Wesern Pacific species Euconchoecia pacifica is redescribed, and the status of currently known members of the genus reviewed. This review suggests that the genus includes 21 species. Nine of these have been previously described in the literature, two more were originally described as subspecies, but herein are raised to full specific rank. It is also evident from the literature that at least a further seven species have been miss-attributed to the known species. These latter ten species have only been partially described, and so have been left in open nomenclature. For the North-Western Pacific 14 species of the genus Euconchoecia are noted. A key to all these species is presented.
\end{abstract}

Keywords: pelagic ostracods; Halocyprididae; Euconchoecia; taxonomy, North Pacific

\section{Introduction}

Pelagic ostracods of the genus Euconchoecia Müller, 1890 inhabit the tropical and subtropical zones of the World Ocean predominantly occurring in the upper surface layers. Currently seven species and two subspecies have been attributed to this genus. However, studying our collections and the literature has shown that the genus needs substantial revision. First we redescribe E. pacifica and illustrate this species in detail. We revise the genus to include 21 species (Table 1). In addition to the nine extant species, two forms previously considered to be subspecies (E. chierchiae aspicula Deevey, 1982 and E. bifurcata pax Kornicker, 1989) are raised to full specific rank. A further seven species are left in open nomenclature and three species are as "affinis" for two known species. These have clearly been incorrectly attributed to other species. However, the reports of these species have been accompanied by descriptions and illustrations that while they are detailed enough to reject the original identifications, they are too inadequate to be definitive descriptions of new species.

In the North-Western Pacific we note 14 species of the genus Euconchoecia, three of which are described below. The key to all these species and list the list characteristics that distinguish them one from one another. 
Table 1. Systematic position of ostracods in genus Euconchoecia Müller, 1890

\begin{tabular}{|c|c|}
\hline Literary date & Proposed system \\
\hline \multirow[t]{2}{*}{ 1. E. chierchiae chierchiae Müller, 1890} & 1. E. chierchiae Müller, 1890 \\
\hline & $\begin{array}{l}\text { 2. E. species } 1 \text { [= E. chierchiae Müller, } 1891 \text { sensu Tseng, } 1969 \text {, } \\
\text { 1980] }\end{array}$ \\
\hline 2. E. chierchiae aspicula Deevey, 1982 & 3. E. aspicula Deevey, 1982 \\
\hline \multirow{5}{*}{ 3. E. aculeata (Scott, 1894) } & 4. E. aculeata (Scott, 1894) \\
\hline & 5. E. species 2 [= E. aculeata (Scott, 1894) sensu Müller, 1906] \\
\hline & $\begin{array}{l}\text { 6. E. species } 3 \text { [= E. aculeata (Scott, 1894) sensu Tseng, 1969, 1980; } \\
\text { Chen, Lin, } 1995\end{array}$ \\
\hline & 7. E. species 4 [= E. aculeata (Scott, 1894) sensu Chen et al., 1983] \\
\hline & 8. E. aff. aculeate sensu Angel et Graves, 2013 \\
\hline \multirow[t]{4}{*}{ 4. E. elongata Müller, 1906} & 9. E. elongata Müller, 1906 \\
\hline & $\begin{array}{l}\text { 10. E. species } 5 \text { [= E. elongata Müller, } 1906 \text { sensu Tseng, } 1969 \text {, } \\
\text { 1980; Chen, Lin, 1995] }\end{array}$ \\
\hline & 11. E. aff. elongate A Angel et Graves, 2013 \\
\hline & 12. E. aff. elongate B Angel et Graves, 2013 \\
\hline \multirow[t]{2}{*}{ 5. E. bifurcata bifurcata Chen, 1985} & 13. E. bifurcata Chen, 1985 \\
\hline & 14. E. species 6 - herein \\
\hline 6. E. bifurcata pax Kornicker, 1989 & 15. E. pax Kornicker, 1989 \\
\hline 7. E. shengwai Tseng, 1969 & 16. E. shengwai Tseng, 1969 \\
\hline \multirow[t]{5}{*}{ 8. E. maimai Tseng, 1969} & 17. E. maimai Tseng, 1969 \\
\hline & 18. E. species 7 [= E. maimai Tseng, 1969 sensu Chen, Lin, 1995] \\
\hline & 19. E. pacifica Chavtur, 1976 \\
\hline & 20. E. omanensis Graves, 2011 \\
\hline & 21. E. hormusensis Graves, 2011 \\
\hline
\end{tabular}

The following abbreviations are used in the illustrations:

r.sh - Rod sharped organ

1-6 - first-sixth segments of the first antenna

$\mathrm{a}-\mathrm{e}$ - terminal setae of the first antenna

$\mathrm{pr}$ - protopodite

ep - epipodite

bas - basale

ex - exopodite

en, en1, en2, en3 - endopodite, first-third segments on endopodite of the second antenna, maxilla, mandible, fifth and sixth limbs

ep.p - epipodial plate on the fifth and sixth limbs

$\mathrm{cx}$ - coxale

prcx - precoxale

c.e - cutting edge on the coxale of the mandible

d.tl - distal tooth-list on the coxale of the mandible

p.tl-posterior tooth-list on the coxale of the mandible

m.p. - masticatory pad on the coxale of the mandible

e.b - endite on the basale of the mandible

I, II - first and second endites on the fifth limb

ho - hook on the endopodite of the second antenna

c.ap - copulatory appendage

c.fu - caudal furca 


\title{
VLADIMIR G. CHAVTUR
}

\section{Taxonomy}

\author{
Order HALOCYPRIDA Dana, 1853 \\ Suborder Halocypridina Dana, 1853 \\ Superfamily Halocypridoidea Dana, 1853 \\ Family Halocyprididae Dana, 1853 \\ Subfamily Euconchoecinae Poulsen, 1969 \\ Genus Euconchoecia Müller, 1890
}

\section{Euconchoecia pacifica Chavtur, 1976}

(Figs. 1-5)

Euconchoecia pacifica Chavtur, 1976: 100-104, Figs. 2-4; Chavtur, 1977: 20 (list)

Euconchoecia maimai: Tseng, 1969 sensu Chavtur, 1991: 43; 1992: Table 2 (part)

Holotype: adult female, length $1.55 \mathrm{~mm}$, valves in alcohol and appendages mounted on slides; reference number N2772 (ex N17665) in collection of the Museum of Institute of Marine Biology, Vladivostok, Russia (together with paratype).

Type locality: $33^{\circ} 40^{\prime} \mathrm{N}, 138^{\circ} 12^{\prime} \mathrm{E}$; depth: 0-100 m; net: $0.1 \mathrm{~m}^{2}$ Juday net; date 14 May 1967.

Paratype: adult male, length $1.55 \mathrm{~mm}$, valves in alcohol, appendages mounted on slides; reference number N2773 in collection of the Museum of Institute of Marine Biology, Vladivostok, Russia. From same sample as the holotype.

Table 2. Records of Euconchoecia pacifica. All specimens were collected using a Juday Net, except that from Vityaz Stn 6151 which were collected using a $1 \mathrm{~m}^{2}$ Bogorov-Rass Net. *indicates specimens that have subsequently been lost.

\begin{tabular}{|c|c|c|c|c|}
\hline \multicolumn{5}{|c|}{ Material studied } \\
\hline $\mathbf{R V}$ & Date & Depth m & Position & Material \\
\hline Orlyk & $29 / 5 / 67$ & $0-100$ & $31^{\circ} 30^{\prime} \mathrm{N} 149^{\circ} 00^{\prime} \mathrm{E}$ & $\mathrm{N} 2775 \stackrel{+}{ } 1.54 \mathrm{~mm}$ \\
\hline SRT 662 & $16 / 7 / 53$ & $0-200$ & $35^{\circ} 14^{\prime} \mathrm{N} 152^{\circ} 07^{\prime} \mathrm{E}$ & $\mathrm{N} 2774$ ๙ $1.60 \mathrm{~mm}$ \\
\hline Vityaz Cr 39 & $29 / 6 / 69$ & $0-50$ & $37^{\circ} 38.6^{\prime} \mathrm{N} 143^{\circ} 51.5^{\prime} \mathrm{E}$ & $\mathrm{N} 2776$ q $1.55 \mathrm{~mm}$ \\
\hline \multicolumn{5}{|c|}{ Additional material } \\
\hline SRT 662 & $11 / 7 / 53$ & $50-100$ & $39^{\circ} 21^{\prime} \mathrm{N} 152^{\circ} 07^{\prime} \mathrm{E}$ & $2 q \mathrm{~s}$ damaged \\
\hline SRT 662 & $16 / 7 / 53$ & $50-100$ & $35^{\circ} 14^{\prime} \mathrm{N} 152^{\circ} 07^{\prime} \mathrm{E}$ & Juv. $1.2 \mathrm{~mm}$ \\
\hline SRT 662 & $16 / 7 / 53$ & $50-100$ & $35^{\circ} 14^{\prime} \mathrm{N} 152^{\circ} 07^{\prime} \mathrm{E}$ & $\mathrm{A}-1$ ㅇ $1.38 \mathrm{~mm}$ \\
\hline Vityaz Cr 19 & $29 / 6 / 54$ & $32-60$ & $40^{\circ} 03^{\prime} \mathrm{N} 143^{\circ} 18.8^{\prime} \mathrm{E}$ & Juv. $1.1 \mathrm{~mm}$ \\
\hline Vityaz Cr 19 & $29 / 6 / 54$ & $58-120$ & $40^{\circ} 03^{\prime} \mathrm{N} 143^{\circ} 18.8^{\prime} \mathrm{E}$ & Juv. $1.2 \mathrm{~mm}$ \\
\hline Vityaz Cr 20 & $2 / 5 / 55$ & $150-1000$ & $37^{\circ} 39.8^{\prime} \mathrm{N} 144^{\circ} 30.1 \mathrm{E}$ & $2 \widehat{\jmath} \mathrm{s} 1.55,1.60 \mathrm{~mm}^{*}$ \\
\hline Vityaz Cr 20 & $3 / 5 / 55$ & $200-500$ & $37^{\circ} 18.2^{\prime} \mathrm{N} 145^{\circ} 16.2^{\prime} \mathrm{E}$ & ㅇ 1.58 ; juv. $*$ \\
\hline Orlyk & $30 / 4 / 67$ & $0-100$ & $37^{\circ} 00^{\prime} \mathrm{N} 149^{\circ} 00^{\prime} \mathrm{E}$ & 우 $1.55 \mathrm{~mm}$ \\
\hline Orlyk & $15 / 5 / 67$ & $0-100$ & $33^{\circ} 40^{\prime} \mathrm{N} 138^{\circ} 12^{\prime} \mathrm{E}$ & $\begin{array}{l}\text { + } 1.60 \text {; } \\
\text { Juv. } 1.22 \mathrm{~mm} *\end{array}$ \\
\hline Orlyk & $29 / 5 / 67$ & $0-100$ & $31^{\circ} 30^{\prime} \mathrm{N} 149^{\circ} 00^{\prime} \mathrm{E}$ & $\begin{array}{l}\text { a- } 1 \text { }+1.38 \mathrm{~mm} \\
2 \text { juvs. * }\end{array}$ \\
\hline Izumrud & $16 / 6 / 69$ & $0-100$ & $37^{\circ} 20^{\prime} \mathrm{N} 134^{\circ} 30^{\prime} \mathrm{E}$ & $4 \bigcirc$ damaged \\
\hline Vityaz Cr 39 & $29 / 6 / 69$ & $0-50$ & $37^{\circ} 38.6^{\prime} \mathrm{N} 143^{\circ} 51.5^{\prime} \mathrm{E}$ & $3 \circ \mathrm{s} 1.52-1.55 \mathrm{~mm}$ \\
\hline
\end{tabular}




\section{MORPHOLOGY AND SYSTEMATICS OF EUCONCHOECIA}

\section{Redescription of adult male}

Carapace (Fig. 1A, B). Length $1.55-1.60 \mathrm{~mm}$. Height is $\sim 50 \%$ of length. The carapace is moderately elongate, with maximum height just anterior to the midpoint, so the anterior half of the shell is marginally larger than the posterior half. The ventral margin curves smoothly from below the rostral incisure to the posterior dorsal corner. The posterior margin forms an angle of about $90^{\circ}$ with the dorsal margin. The postero-dorsal corners in both valves are rounded and lack spines. The rostrum points almost straight; it is rather broad and symmetrical. The shoulder vault is moderately developed and rounded. Surface of the carapace has no perceptible sculpture and no hairs. Each valve has a gland opening just ventral to postero-dorsal corner. Valves are thin.

Rod-sharped organ (Fig. 1C) is slim with a rounded tip. It is shorter than the first antenna reaching about as far as distal end of the second segment.

First antenna (Fig. 1C). The first segment has disto-ventrally rather developed, verruciform, rounded process. The fifth segment ventrally bears 23-25 sensory filaments, which are about half as long as the limb. The a-seta is about $75 \%$ length of the second segment. The b-seta is about $75 \%$ length of the rod-sharped organ and somewhat shorter than the sensory filaments. The d-seta is about $3 \frac{1 / 2}{2}$ times the length of the second segment. The e-seta is longest, slightly widened and flattened distally and about 1.5 times the length of the limb.

Second antenna (Fig. 1D-H). The exopodite is about $70 \%$ the length of the protopodite. The first exopodite segment is about twice the combined length of the other eight segments, which carry the long setae with natatory hairs. The natatory setae are subequal to the protopodite. On the endopodite the "a" and "b" setae on the first segment comparatively short, weak and bare. The " $b$ " seta is about $1 \frac{1}{2}$ times the length of the "a" seta and is more than half the length of the second segment. The dorsal surface of the first segment has a covering of short fine hairs. The elongate second segment is half the length of the first segment and is broadest near its midpoint. The right endopodite is terminally rounded with a very developed sclerotized bulge, whereas the left endopodite has a slight chitined knob. The longest terminal seta on the right endopodite is about 3 times the length of the protopodite and $3 \frac{1}{2}$ times the length of the other terminal seta. The third segment on the left endopodite is prolonged with somewhat thickened base; its dorsal seta is very short and its ventral seta is about half the length of its longest seta. This segment on the right endopodite forms a moderately slender and elongated V-shaped process, which ends in a broadly rounded tip with subterminal ridges. The distal angle of V-shaped process bears 3 filament-like setae, similar to those on same segment of the left endopodite.

Mandible (Fig. 2A). The tooth edge of the coxale has 10 moderately large, simple, smooth, triangular teeth, the second of which (from anterior margin) is considerably larger than the others. The distal tooth-list is only slightly narrower than the tooth edge, and is furnished with 12 teeth, of which the posterior two are very large, tusk-like and smooth; the more anterior one from the others teeth is the largest. The proximal tooth-list, which is very narrow, only a third of the width of the distal tooth-list, consists of 6 smooth teeth ranging in size from moderately large to small. The masticatory pad is very large, the same width as the distal tooth-list. It is simple, with an almost straight distal cutting margin and is armed with very close, short, fine spines. Somewhat proximally of the masticatory pad is a large cavity which has a sharp, raised edge, and which on its inner posterior edge has a dense row of 9 smooth, simple, lancet-like bristles of moderate size. The distal edge of the basal endite bears 6 teeth of about the same width; most of them are serrated; anterior tooth is rather low. There is lateral triangular and serrated tooth. On the posterior end of this edge are two processes, the more anterior one is a very short and bare tube-bristle, and the posterior one is dagger-shaped and furnished with more or less powerful secondary tooth. The basal endite bears two short and two moderately long setae. The epipodial appendage is well developed and bears very long seta, which sparsely hairy and is about as long as the anterior side of the two proximal endopodite segments. The exopodite is represented by a single plumose seta, which is about as long as a half of the endopodite. The first segment of the endopodite has antero-distally 


\section{VLADIMIR G. CHAVTUR}

a very short, bare seta and posteriorly three setae with short, fine hairs; these setae are differ in length, but are all are shorter than the segment. The second segment bears antero-distally one long (about half the length of the endopodite and about $65-70 \%$ the length of the main terminal claw-like seta), stout seta armed with spines, and another moderately long seta with short hairs. The posterior side of its segment has one short seta furnished with short, fine hairs. There are seven terminal setae on this segment, the third of which (counting from the front) is very powerful, coarsely spinose and claw-like; it is about $75 \%$ or somewhat more than the length of the endopodite and about $3 \frac{1}{2}$ times the length of its third segment. The most anterior of the terminal seta is similarly spinose and about $65-70 \%$ the length of the main claw-like seta.

Maxilla (Fig. 2B-F). The endite on the precoxale bears 7 bristles, of which the inner anterior one and the two outermost posterior ones are tube-bristles. The endite on the coxale is armed with 14 bristles, 6 on the anterior process and 8 on the posterior process. Each process carries 2 tube-like bristles. The basale has a single short seta, which extends well short of the distal boundary of the first endopodite segment. Along the anterior edge of the first endopodite is a row of 5 long setae of differing length; the longest being longer than the segment, the shortest as long as its width. All these setae have short and fine hairs. This segment also carries a few rows of long hairs. There are three more unequal setae on the posterior face of the first segement; the longest seta is as long as the width of the segment. There is also an inner seta on this segment is displaced posteriorly, and is situated close to three posterior setae. This inner seta is subequal in length to the basale seta. The terminal segment is comparatively short, only about half the breadth of the first endopodite segment and fairly stout. It bears six terminal setae, the most posterior of which is strong, long, subequal to the length of the first endopodite segment and about twice as long as the second segment. The most anterior is stout and is fused with segment (there is no suture) and its length is about half the width of the segment. The anterior face of this terminal segment is covered with long hairs.

Fifth limb (Fig. 2G, H). The epipodial plate has 5, 4 and 5 (one short) in the distal, middle and proximal groups respectively. The first endite of precoxale has two setae, the proximal one of which is a short and armed with short hairs, the other is plumose and about as long as breadth of this segment. The second endite bears three setae, two of which are similar in type and length as the short seta on the first endite, the third is similar in type but somewhat shorter than the longer seta on the first segment. The coxale bears eight setae. Two of these, are inserted close to the protopodite, one proximally on the anterior side of the process close to the protopodite, the other ventrally near the exopodite, are of the same type and of similar length as the long setae on the endites of the protopodite. The others setae have short hairs, and differ in length, two of these, which are inserted disto-ventrally on the process, are rather powerful. The basal segment has five ventral setae of different lengths with short hairs and laterally two long plumose setae inserted near the middle of the segement. The ventral and dorsal surfaces of this segment are hirsute proximally. The exopodite is represented by very long seta with fine hairs. The first segment of endopodite bears two ventral and one dorsal setae of moderate length with short fine hairs. The second segment has three terminal setae, the middle one is finely pectinate and powerful being somewhat longer than endopodite. The other two terminal setae are shorter and weaker and are lined with short and fine hairs.

Sixth limb (Fig. 2I, J). It is large and powerful. The epipodial plate has 5, 5 and 7 (one short) setae in the distal, middle and proximal groups respectively. The protopodite bear two disto-ventral subequal setae with short, fine hairs. These setae are as long as or slightly shorter than the width of the protopodite. The basal segment is provided with five setae scattered along the ventral side and somewhat medially similar to the two on the endopodite. These setae are about as long as or slightly shorter than height of this segment. Laterally at about the middle point of the segment there is another seta of the same type, which is about the same length as the shortest ventral seta. There are also a number of rather long soft hairs distributed on the ventral surface of this segment. The exopodite is represented by short seta with short, fine hairs. It is about as long as the height of following segment. The first segment of endopodite has only two ventral subequal setae, which are about half or slightly less the length of the segment. The second segment has two ventral and one dorso-distal seta, all of which carry short hairs. These setae are about as long as or somewhat shorter than its segment. There are 


\section{MORPHOLOGY AND SYSTEMATICS OF EUCONCHOECIA}

three similar setae on the third segment, which are subequal, plumose and about as long as or slightly longer than the endopodite.

Copulatory appendage (Fig. 3A, B). This is relatively long, slightly curved upward and with small protuberance at the tip. It narrows close to its base, but then broadens to its maximum width at midlength. The ratio between the appendage's length (i.e. from its tip to its minimum width) and the distance between the bases of the first and seventh pairs of caudal furca claws is about 1.7:1. The organ has 7-11 oblique muscle bands.

Caudal furca (Fig. 3A, B). Each lamella bears seven slender claws, and an unpaired bristle is present. On each lamella between the insertions of the first and second claws is a small process. The ratio between the length of the first claw and the height of the furca (i.e., the distance between the insertions of the first and seventh claws) is about 1.5:1.

\section{Redescription of adult female}

Carapace (Fig. 3D, E). It shows some sexual dimophism from that of the male. The length ranges from 1.55 to $1.60 \mathrm{~mm}$. Its height is about $50 \%$ of its length. The rostrum is somewhat straighter and postero-ventral margin somewhat more oblique than in the male. The shoulder vault is less distinct. The surface of the carapace has faintly striated.

Frontal organ (Fig. 3F). It is similar to the male's and reaches to about the midpoint of the third segment of the first antenna.

First antenna (Fig. 3F). It has no disto-ventral process on the first segment. There are 23 ventral setae on the fifth segment, which are three-quarters the length of the limb.

Second antenna (Fig. 3G-I). The lengths of the protopodite and exopodite are relatively shorter than in the male, but the ratio between their lengths is similar. The endopodite is also smaller. The setae on the first endopodite segment are similar in type and length to those in the male. The second segment is about a third the length of the first segment. The fused third segment bears one long seta, which is about as long as or slightly shorter than the overall length of the endopodite.

Mandible (Fig. 4A-F). There is only minor sexual dimorphism, with only differences in the sizes of some setae. The main claw on the terminal segment in female it is somewhat longer and about as long as the exopodite. The seta on the second exopodite segment is also longer in the female - about two-thirds the length of the exopodite.

Maxilla (Fig. 4G-I). Very similar to the male's differing only in the number of setae on the coxal endite, which has only five setae on the anterior process and five on the posterior process.

Fifth limb (Fig. 5A-C). Similar in female to the male.

Sixth limb (Fig. 5D). In the female this is a considerably smaller and weaker limb than in the male. There is only one seta on the ventral side of the second endopodite segment. The dorsal and middle setae of the terminal segment are about as long as the total length of the three distal segments; its ventral seta is subequal in length to the basal segment.

Caudal furca: the same as in male.

\section{Remarks}

Although this species is closely related to Euconchoecia maimai Tseng, 1969, from the Taiwan Straits, but it differs in many respects (Table 3)

Euconchoecia pacifica is also similar to Euconchoecia species 7, but is distinguishable from it on the basis of the length of the carapace and structure of the clasping organ on the right second antenna.

\section{Distribution}

This species inhabits in the subtropical waters of the Japan Sea (Chavtur, 1976; 1977) and the Pacific Ocean near Japan in the area bounded by $31^{\circ}-40^{\circ} \mathrm{N}$ and $138^{\circ}-152^{\circ} \mathrm{E}$ (Chavtur, $\left.1977 ; 1991 ; 1992\right)$ generally in the 


\section{VLADIMIR G. CHAVTUR}

depth range 0-200 (500) $\mathrm{m}$, but it was also caught in a tow from 1000 to $150 \mathrm{~m}$.

Table 3. List of character distinguishing Euconchoecia pacifica Chavtur and E. maimai Tseng

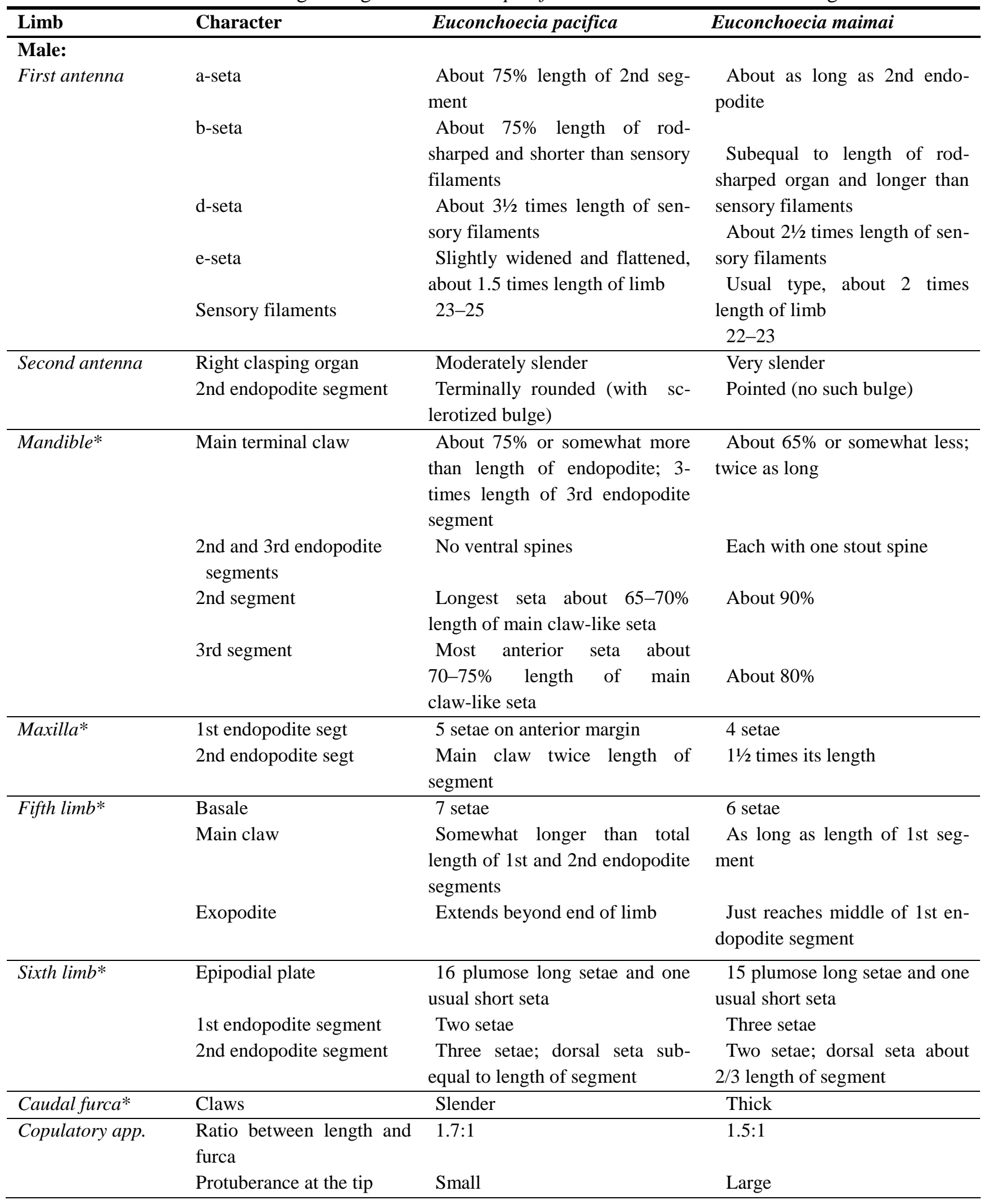

* These limbs are not described for female of the E. maimai 


\section{MORPHOLOGY AND SYSTEMATICS OF EUCONCHOECIA}

\section{Euconchoecia maimai Tseng, 1969}

Euconchoecia maimai Tseng, 1969: 7-11, Fig. 2.

Not Euconchoecia maimai Tseng, 1969 sensu Chen, Lin, 1995: 50-51, Fig. 56.

\section{Distribution}

This species occurs in the shallow waters of the Taiwan Straits between $21-25^{\circ} \mathrm{N}$ and $117-120^{\circ} \mathrm{E}$ (Tseng, 1969; 1970a; 1970b; Hanai et al., 1980; Chen, 1982).

\section{Euconchoecia species 7}

Euconchoecia maimai Tseng, 1969 sensu Chen, Lin, 1995: 50-51, Fig. 56.

\section{Remarks}

This species is closely related to both E. maimai and E. pacifica, but is much smaller than both these species. In addition, it differs from E. maimai in a having thicker right clasper on the second antenna, and from E. pacifica in that it lacks the sclerotized protuberance on the distal endopodite segment on the right second antenna.

\section{Distribution}

This species has been collected in the China Seas (Chen and Lin, 1995).

\section{Euconchoecia chierchiae Müller, 1890}

Euconchoecia chierchiae Müller, 1890: 277-278, Taf. 28, Figs. 1-10; 1906: 128, Taf. 32, Fig. 8-17; Brady, 1902: 190, Pl. 24, Figs. 9-15; Skogsberg, 1920: 740-755, Figs. 148-151; Deevey, 1968: 116-118, Fig. 62; Poulsen, 1969a: 38-40, Figs. 12, 13.

Paraconchoecia oblonga Claus, 1890 sensu Cleve, 1900: 40.

Not Euconchoecia chierchiae Müller, 1890 sensu Tseng, 1969: 2-6, Fig. 1; 1980: 416-417, Fig. 9.

\section{Distribution}

Circumtropical - subtropical interzonal species (Vinogradov, 1968, pp. 50-52: interzonal species inhabited in shallow and deep zones). It widely inhabits mainly shallow waters, but also in the open ocean in the tropical and subtropical region of the all oceans. In the East Atlantic (dividing line between East and West Atlantic is arbitrarily considered to be along $30^{\circ} \mathrm{W}$ ), it has been recorded from between $18^{\circ} \mathrm{N}$ and $5^{\circ} \mathrm{S}$ and $26^{\circ} \mathrm{W}-10^{\circ} \mathrm{E}$ at depths from the surface to $900 \mathrm{~m}$ (but most abundantly at depths of 0-200 m) and in vertical tows from 2000-0 m (Brady, 1902; Vavra, 1906; Müller, 1906; 1912; Scott, 1912; Seguin, 1966; Poulsen, 1969a; 1969b; Bainbridge, 1972; Angel and Fasham, 1975; Moguilevsky and Angel, 1975). In the Western Atlantic and Gulf of Mexico, it has been recorded from $42^{\circ} \mathrm{N}$ to $43^{\circ} \mathrm{S}$ and $33^{\circ}$ to $75^{\circ} \mathrm{W}$ from depths ranging from $0-1700 \mathrm{~m}$, but mainly from 50-200 m (Müller, 1890; Cleve, 1900; Vavra, 1906; Scott, 1912; Müller, 1912; Skogsberg, 1920; Barney, 1921; Deevey, 1952; 1960; 1968; 1970; 1971; 1978; 1982; Deevey, Brooks, 1982; Darby, 1965; Hopkins, 1966; Poulsen, 1969a; Baker et al., 1977; Angel, 1979; Gonzales, Breman, 1982; Drapun, 1983; Falavigna, 1983; Graves, 2011).

In the Indian Ocean, its recorded range is $19^{\circ} \mathrm{N}$ to $34^{\circ} \mathrm{S}$ and $34^{\circ}$ to $113^{\circ} \mathrm{E}$ from depths of 0 to $530 \mathrm{~m}$, but also in vertical tows from 1500-2500m (Müller, 1906; 1908; 1912; Cleve, 1904; 1905; Leveau, 1967; 1969; 


\section{VLADIMIR G. CHAVTUR}

Leveau, Szekielda, 1968; Poulsen, 1969a; George, 1969; Motoda et al., 1972; Okera, 1974; George, Nair, 1980; Hanai et al, 1980). Cleve (1904) also reported at shallow depths in the Red Sea between $15-16^{\circ} \mathrm{N}$ and $41-42^{\circ} \mathrm{E}$.

In the South-West Pacific, this species has been reported in the Australian coastal waters of the New South Wales (Broken Bay and Port Jackson) (Dakin and Colefax, 1940). It has also been caught in the China Seas (Chen and Lin, 1995) and near Taiwan between $21^{\circ}-26^{\circ} \mathrm{N}$ and $120-124^{\circ} \mathrm{E}$ from depths of $0-300 \mathrm{~m}$ (Poulsen, 1969a; Hanai et al., 1980). Poulsen (1969a) reported it from the Eastern Pacific at $21^{\circ} \mathrm{N}-29^{\circ} \mathrm{S}$ and $124^{\circ}-179^{\circ} \mathrm{E}$ at depths ranging from $0-150 \mathrm{~m}$.

\section{Euconchoecia species 1}

Euconchoecia chierchiae Müller, 1890 sensu Tseng, 1969: 2-6, Fig. 1; 1980: 416-417, Fig. 9.

\section{Remarks}

This species is closely related to E. chierchiae, but differs in the following respects; postero-dorsal spine on the right valve of females is situated well below of the dorsal margin (c.f at the margin in E. chierchiae), the first antenna of the male has 21-24 sensory filaments (c.f. 25-27 filaments), the base of the clasping organ on the right second is short and thick (c.f. elongate and narrow), the copulatory appendage is very broad (c.f. moderately broad), the furcal claws are slender (c.f. stout).

\section{Distribution}

This species has only been found only in the Taiwan Straits and in the coastal waters of Hong Kong at depths of 7-50 m (Tseng, 1969; 1980).

\section{Euconchoecia aculeata (Scott, 1894)}

Halocypris aculeata Scott, 1894: 142-143, Pl. 15, Figs. 5, 6, 33, 34, 38

Euconchoecia aculeata (Scott, 1894): Poulsen, 1969a: 41-42, Fig. 15.

Not Euconchoecia aculeata (Scott, 1894) sensu Müller, 1906: 129, Taf. 32, Fig. 18-20, 22, 23, 25, 26; Tseng, 1969: 18-22, Fig. 4; 1980: 418-422, Pl. 3.; Chen and Lin, 1995: 43, Fig. 52; Chen, Yin and Zhang, 1983: 129-130, Fig. 54.

\section{Distribution}

In the Atlantic Ocean, this species is only known from tropical shallow water at $0^{\circ} 12^{\prime} \mathrm{S}-7^{\circ} 19^{\prime} \mathrm{E}$ (Scott, 1894 ) and $8^{\circ} 14^{\prime} \mathrm{N}-13^{\circ} 27^{\prime} \mathrm{W}$ (Poulsen, 1969a). In the Indian Ocean, it occurs in all shallow sea areas from the equator to its north boundary, including the Red Sea, Arabian Sea, Persian Gulf, Gulf of Aden and Oman Gulf at depth ranges of 0-200 m (Leveau and Szekielda, 1968; Leveau, 1969; George, 1969; McKenzie et al., 1979; George and Nair, 1980). In the South Pacific, it has been caught off Australia in the coastal waters of New South Wales (Dakin and Colefax, 1940) and also from areas between $9-29^{\circ} \mathrm{S}$ and $124-156^{\circ} \mathrm{E}$ near the surface (Müller, 1906; Poulsen, 1969a; Hanai et al., 1980). In the North-East Pacific, E. aculeata was reported from the coastal waters near San Salvador (Hartmann, 1957) and in the region $7^{\circ} 55 \mathrm{~N}-79^{\circ} 02^{\prime} \mathrm{W}$ in the depth 50 $\mathrm{m}$ (Poulsen, with disto-ventral sclerotized bulge)

1969a). In the North-West Pacific, it has been taken only from the regions $4^{\circ} 08 \mathrm{~N}-123^{\circ} 08 \mathrm{E}$ and $7^{\circ} 14 \mathrm{~N}-114^{\circ} 49^{\prime} \mathrm{E}$ at depth $25-75 \mathrm{~m}$ (Poulsen, 1969a; Hanai et al., 1980). 


\section{MORPHOLOGY AND SYSTEMATICS OF EUCONCHOECIA}

\section{Euconchoecia species 3 (Figs. 6 and 7)}

Euconchoecia aculeata (Scott, 1894) sensu Tseng, 1969: 18-22, Fig. 4; 1980: 418-422, Pl. 3; Chen, Lin, 1995: 43, Fig. 52.

Studied material: - Adult female, length $1.0 \mathrm{~mm}$, station 58 of R/V "Cavalerovo", 1 September 1980, $34^{\circ} 29^{\prime} \mathrm{N} 140^{\circ} 45^{\prime} \mathrm{E}$, depth $0-100 \mathrm{~m}$, in Juday Plankton Net $(\mathrm{S}=0.1 \mathrm{~m} 2)$, appendages mounted on slide and valves in alcochol. Specimen N 2779 In collection of the Museum of Institute of Marine Biology, Vladivostok, Russia.

\section{Description of adult female}

Caracace (Fig. 6A-E). Length $1.0 \mathrm{~mm}$ (exclusive of the postero-dorsal spines); height is $43 \%$ of its length. It is moderately elongated, with maximum height just posterior to the midlength. The dorsal margin is almost straight, and postero-ventral margin is oblique. There is a postero-dorsal spine on each valve; the spine on the right valve is much the longer. The rostrum tapers to fine point. There are carapace glands opening symmetrically just ventral to postero-dorsal corner.

Frontal organ (Fig. 6F). It is somewhat thinner in its distal half. Its tip is rounded and projects well beyond the end of the first antenna.

First antenna (Fig. 6F). The 1st segment is of the usual type and lacks any disto-ventral process. The firth segment bears about 20 sensory filaments, which are similar in length to the limb of the first antenna.

Second antenna (Fig. 6G-I). The exopodite is about $70 \%$ the length of the protopodite. The ratio between the length of the first exopodite segment and the combined lengths of the other segments and also between the length of the protopodite and the exopodite is about 1.5:1. The "a" and "b" bristles on the first endopodite segment are comparatively short, weak and bare. The " $b$ " bristle is about twice the length of the first endopodite segment. The second endopodite segment is elongate, more than a third the length of the protopodite and about 3 times as long as the first segment.

Mandible (Fig. 7A, B). The epipodial appendage is moderately developed. On the ventral side of the first endopodite segment is only a single short seta. There are two setae on the second segment, the shorter of the two is half the length of the longer. The third segment appears to carry only 6 (?) terminal setae.

Fifth limb (Fig. 7C, D). The first endite of precoxale has 2 setae, of which proximal seta is a short with short hairs, the distal seta is plumose and about as long as breadth of the segment. The second endite bears two similar setae. The coxale carries seven setae, two of which are very short, 2 are of moderate length and remaining 3 (one of which is stout) are about as long as the long setae on the endites. The basale is divided ventrally by a suture, and bears only four ventral setae. The exopodite is represented by long seta with short, fine hairs. This seta is longer than the endopodite. The first segment of endopodite has two ventral and one dorsal seta. The main terminal claw is equal in length to the endopodite. The outside of the precoxale and coxale are covered with long hairs.

Sixth limb (Fig. 6J). The epipodial appendage has 12 long and one short seta. The protopodite carries two disto-ventral quite short, non-plumose setae. The basale segment bears 3 ventral and one lateral seta. The exopodite is represented by seta similar in length as basal setae. The first endopodite segment is bare. The second segment has one ventral seta and one relatively long dorsal seta. The dorsal and middle setae of the distal segment are subequal and about as long as total length of the 3 distal segments.

Others limbs were damaged.

\section{Remarks}

This species is closely related to Euconchoecia aculeata, Euconchoecia species 2, and Euconchoecia species 4. Some differences between this species and E. aculeata (characteristics for E. aculeata in brackets) are:- 1) the frontal organ extends beyond the end of the first antenna (much shorter), and 2) the distal angle of 


\section{VLADIMIR G. CHAVTUR}

the right clasping organ with a protuberant process (Tseng, 1969)(lacks any such protuberance).

This species differs from $E$. species 2 in the following characteristics: -

1) The shapes of the proximal segment of the endopodite of the second antenna in females and the right clasping organ in males.

2) The proportion between the length of the first endopodite segment and the protopodite of the second antenna in females is larger in Euconchoecia species 3, than that in Euconchoecia species 2

3) In Euconchoecia species 3, the tip of the frontal organ is rounded, whereas it is pointed in Euconchoecia species 2

4) In Euconchoecia species 3, the lengths of the sensory filaments on the male first antenna are only about double the height of its limb, but are over three times as long in $E$. species 2

It differs from $E$. species 4 in its small size and sensory filaments of the first antenna being short relative to the height of the limb.

\section{Distribution}

It is known from the shallow waters near the Taiwan Island (Tseng, 1969; 1980; Chen, Lin, 1995), near Japan $\left(34^{\circ} \mathrm{N}, 140^{\circ} \mathrm{E}\right)$ at $0-100 \mathrm{~m}$ (herein). Specimens of Euconchoecia aculeata reported from this region by Poulsen (1969a), Chen (1978, 1982) and Hanai et al. (1980) may also have also belonged to Euconchoecia species 3.

\section{Euconchoecia species 4}

Euconchoecia aculeata (Scott, 1894) sensu Chen, Yin, Zhang, 1983: 129-130, Fig. 54.

\section{Remarks}

This species is closely related to Euconchoecia aculeata, E. species 2 and E. species 3, differing from all these species in its large size and relatively long sensory filaments of the first antenna relative to the height of the limb.

\section{Distribution}

This species has been found over the shelf the northern sector of the South China Sea and also between the islands of Paraselsky and Spratlee (Chen et al., 1983).

\section{Euconchoecia elongata Müller, 1906, new status}

Euconchoecia aculeata var. elongata Müller, 1906: 129, Taf. 32, Fig. 21.

Not Euconchoecia elongata Müller, 1906 sensu Tseng, 1969: 12-17, Fig. 3; Tseng, 1970b: 285, 286, 288, 289, 290, 293, 295; 1976: 201-212, Figs. 1-4; Tseng, 1980: 417-418, Fig. 10; Chen and Lin, 1995: 49-50, Fig. 55.

\section{Distribution}

This species has been described from the Indian Ocean $\left(13^{\circ} 20^{\prime} \mathrm{N}, 46^{\circ} 41^{\prime} \mathrm{E}\right)$ in a vertical tow from $1200 \mathrm{~m}$ to surface (Müller, 1906). The specimens ascribed to Euconchoecia var. elongata by Poulsen (1969a); and by Hanai et al., (1980) from the Malayan Archipelago (one specimen $1.3 \mathrm{~mm}$ long; depth $50-75 \mathrm{~m}$ in $4^{\circ} 08^{\prime} \mathrm{N}$, $123^{\circ} 00^{\prime} \mathrm{E}$ ); and by Motoda et al. (1972) from the area $10^{\circ}-14^{\circ} \mathrm{S}$ and $105^{\circ}-113^{\circ} \mathrm{E}$ (in the upper $200 \mathrm{~m}$ ) may also belong to this species. 


\section{MORPHOLOGY AND SYSTEMATICS OF EUCONCHOECIA}

\section{Euconchoecia species 5}

Euconchoecia elongata Müller, 1906, sensu Tseng, 1969: 12-17, Fig. 3; 1980: 417-418, Fig. 10; Chen, Lin, 1995: 49-50, Fig. 55.

\section{Remarks}

This species differs from E. elongata in following respects (characters for E. elongata in brackets): the length of the shell in females is $>1.5 \mathrm{~mm}(<1.4 \mathrm{~mm})$, the posterodorsal spine on the right valve is situated below of the dorsal margin (spine in line with the dorsal margin), this spine is aligned either parallel to the dorsal margin or is slightly turned down (slightly turned up).

\section{Distribution}

This species has been collected in the coastal waters near the Taiwan Island (Tseng, 1969, and probably Tseng, 1970b; 1975; Chen, 1978; 1982; Poulsen, 1969a; Hanai et al., 1980; ascribed by all these authors to $E$. elongata). The specimens reported as E. elongata from shallow water near the Island Guam at $13^{\circ} 30^{\prime} \mathrm{N}$; $114^{\circ} 40^{\prime} \mathrm{E}$ (Tseng, 1976), the specimens $1.5-1.8 \mathrm{~mm}$ in length reported from the vicinity of the Malayan Archipelago at $4^{\circ} 08^{\prime} \mathrm{N} ; 123^{\circ} 00 \mathrm{E}$ (Poulsen, 1969a; Hanai et al., 1980) and off New South Wales, Australia (Daking and Colefax, 1940) probably also belong to Euconchoecia species 5.

\section{Euconchoecia shenghwai Tseng, 1969}

Euconchoecia shenghwai Tseng, 1969: 23-25, Fig. 5; Chen and Lin, 1995: 51, Fig. 57.

\section{Distribution}

This species was described from the upper $50 \mathrm{~m}$ of the shallow waters of the Taiwan Straits $\left(24^{\circ} 25^{\prime} \mathrm{N} ; 120^{\circ} 36 \mathrm{E}\right.$ and $\left.25^{\circ} 30^{\prime} \mathrm{N} ; 120^{\circ} 30^{\prime} \mathrm{E}\right)$ (Tseng, 1969; Hanai et al., 1980), and also from the China Seas (Chen and Lin, 1995).

\section{Euconchoecia bifurcata Chen and Lin, 1984}

Euconchoecia bifurcata Chen and Lin, 1984: 859-861, Fig. 1; 1985: 131-133, Fig. 1; Chen and Lin, 1995: 47-48, Fig. 53.

\section{Distribution}

This species has been taken in the East China Sea $\left(28^{\circ}-29^{\circ} \mathrm{N}\right.$ and $\left.124^{\circ}-125^{\circ} \mathrm{E}\right)$ in the shallow (?) waters (Chen and Lin, 1984; 1985; 1995).

\section{Euconchoecia pax Kornicker, 1989, new status}

Euconchoecia bifurcata pax Kornicker, Iliffe, 1989: 29-43, Figs. 16-22, Tables 6, 7.

\section{Remarks}

Kornicker's specimens originally described as a subspecies are elevated to full species status because of some sharp differences from the Tseng's specimens. In Euconchoecia pax, the length is considerably smaller; the male frontal organ is flattened and pointed at the tip (bifurcate in E. bifurcata); female frontal organ extends well beyond the tip of the first antenna (barely reaches the end in E. bifurcata); in the male first 


\section{VLADIMIR G. CHAVTUR}

antenna has 18 sensory filaments ( 25 in E. bifurcata); the right clasping organ on the second antenna of the male is shorter and less elongated than in E. bifurcata; the caudal furca carries seven pairs of claws (8 pairs in E. bifurcata).

\section{Distribution}

This cave-dwelling species is known only from Palau, Koror (Oreor) Island, Ngermeuangel, Like 2A Cave (about $7^{\circ} 30^{\prime} \mathrm{N}, 134^{\circ} 30^{\prime} \mathrm{E}$, ca. $800 \mathrm{~km}$ east of the Philippine Island of Mindanao) in the depth 8-36 $\mathrm{m}$ (Kornicker and Iliffe, 1989).

\section{Euconchoecia species 6 (Figs. 8 and 9)}

Material studied: Adult female N2777 (length $1.40 \mathrm{~m}$ ), R/V "Cavalerovo" station 30, 3900N, 149 $00 \mathrm{E}$, depth 0-100 m, August 23, 1980; adult female N2778 (length $1.40 \mathrm{~mm}$ ), R/V "Cavalerovo" station 54, $36^{\circ} 20^{\prime} \mathrm{N}, 142^{\circ} 30^{\prime} \mathrm{E}$, depth $0-100 \mathrm{~m}$, August 30, 1980; collected in a Juday Plankton Net ( $\left.\mathrm{S}=0.1 \mathrm{~m} 2\right)$, appendages mounted on slides and valves in alcohol. In collection of the Museum of Institute of Marine Biology, Vladivostok, Russia.

\section{Description of adult female}

Carapace: (Fig. 8A-I). The length $1.40 \mathrm{~mm}$ (exclusive of postero-dorsal spine); height $29 \%$ of its length. The carapace is very elongated, with its maximum height at midlength. In lateral view the dorsal margin is straight and the ventral margin is convex. Both carapace valves with a postero-dorsal spine, the spine on the right valve is considerably longer. Carapace glands open symmetrically just ventral to postero-dorsal corner. The postero-ventral margin is oblique.

Frontal organ: (Fig. 8J-L and 9A) is very slender in its distal half and just extends beyond the end of the 1 st antenna. Its tip is bifurcate.

First antenna: (Fig. 8L and 9A). The 1st segment is usual type. The limb bears 20-21 sensory filaments, which are about 1.2 times the length of the limb. The second segment is a little shorter than third.

Second antenna: (Fig. 9B, C). The short seta on the first endopodite segment is shorter than the second segment. The seta of the third segment is about as long as the first segment.

Mandible: (Fig. 9D, E). The exopodite is represented by one long plumose seta, which is somewhat longer than the first endopodite segment. The ventral side of the first endopodite segment bears two setae. The short dorsal seta on the second segment does not extend as far as the end of the limb. The third segment is slim.

Fifth limb: (Fig. 9F). The basale segment bears four usual short ventral setae with short hairs and one long plumose lateral seta. The exopodite is represente by very long short-haired seta. This seta is subequal to total the basale and endopodite. The first endopodite segment has two ventral and one dorsal short setae, and second segment has the three terminal setae, which typical for genus.

Sixth limb: (Fig. 9G). The basale segment has four ventral and one lateral setae. The seta of exopodite is about as long as or slightly longer than the following segment. The first endopodite segment has one ventral seta and the second segment has one ventral seta and one dorsal seta. The dorsal and middle setae of the terminal segment are subequal; the third (ventral) seta is a little less than half the length of these other setae.

\section{Remarks}

This species is closely related to E. bifurcata, but differs by sized of the carapace, its posterior-dorsal spine placed on right valve and frontal organ, and number of sensory filaments on the first antenna. 


\section{MORPHOLOGY AND SYSTEMATICS OF EUCONCHOECIA}

\section{Key to the 14 species of genus Euconchoecia}

Now, 21 species of the genus Euconchoecia are known (Table 1). Below is given provisional keys only for species from the North-Western Pacific.

\section{Key to Males}

1a. Postero-dorsal corners of both valves are evenly rounded and lack spines.

1b. Postero-dorsal corner of one or both valves is armed with spine (the right valve of E. aspicula lacks a spine but is angled)

3a. Second segment of endopodite on right second antenna with large sclerotized disto-dorsal protuberance; claws of caudal furca are slim, second claw is c.60\% length of first E. pacifica

3b. Second segment of endopodite on right second antenna lacks a large sclerotized disto-dorsal protuberance; claws of caudal furca are stout, second claw is c. $85 \%$ length of first E. maimai

4a. Tip of frontal organ is bifurcate E. bifurcata

4b. Tip of frontal organ is non-bifurcated 5.

5a. Only postero-dorsal corner of right carapace valve armed with a spine. 6.

$5 b$. Postero-dorsal corners of both carapace valves armed with a spine 7.

6a. Frontal organ extends well beyond end of first antenna; each first antenna carries 28-29 sensory filaments. E. shenghwai

6b. Frontal organ shorter than first antenna; each first antenna carries 21-24 sensory filaments.... E. chierchiae

7a. Height of carapace $>40 \%$ of its length of it 8.

7b. Height of carapace $<40 \%$ of its length Euconchoecia species 5

8a. Length of carapace $>1.5 \mathrm{~mm}$. Euconchoecia species 4

8 b. Length of carapace $<1.4 \mathrm{~mm}$. 9.

9a. Frontal organ much shorter than first antenna.

9b. Frontal organ equal to or longer than first antenna

10a. Maximum carapace height anterior to midline; base of clasper of right second antenna thick, considerably thicker than its distal part. Euconchoecia species 1

10b. Maximum carapace height at midlength; both basal and distal sections of clasper on right second antenna thin and of similar thickness. E. aculeata

11a. Frontal organ flattened distally and extending well beyond down-curved distal segments of first antenna (cave-dwelling species) .... E. pax

11b. Frontal organ unflattened, barely extending beyond down curving distal segments of first antenna........12. 


\section{VLADIMIR G. CHAVTUR}

12a. Maximum carapace height less than half its length, knee of right clasper of second antenna with a process Euconchoecia species 3

12b Maximum carapace height equal to half its length, knee of right clasper of second antenna lacks a process Euconchoecia species 2

\section{Key to Females}

1a. Height of carapace $\geq 50 \%$ length, postero-dorsal corners of both carapace valves evenly rounded. 2

1b. Height of carapace $<50 \%$ length, postero-dorsal corner of at least one valve armed with spine (the right valve of E. aspicula lacks a spine but is angled).

3a. Furcal claws are slim, length of second claw ca. $60 \%$ of first

6a. Carapace length $<1.5 \mathrm{~mm}$, breadth of first antenna is ca.30\% of its length, and it bears $20-21$ sensory filaments

6b. Carapace length $>1.7 \mathrm{~mm}$, breadth of first antenna is ca.15-20\% of its length and bears 25 sensory filaments.

7a. Carapace height ca. $40-50 \%$ of its length...... 8.

7b. Carapace height ca. $30 \%$ of its length. 15.

8a. Postero-dorsal corner of right carapace valve only with spine 9.

8 b. Postero-dorsal corners of both carapace valves carry a spine 10.

9a. Rostrum of both right and left valves of similar length; first 1st antenna with 28-29 sensory filaments

9b. Rostrum on left carapace valve is much longer than on right valve, first antenna with 21-23 sensory filaments. E. chierchiae

10a. Length of carapace $>1.5 \mathrm{~mm}$ Euconchoecia species 4

10b. Length of carapace $<1.3 \mathrm{~mm}$

11a. Frontal organ shorter than limb of first antenna.

11b. Frontal organ far longer than limb of first antenna

12a. Postero-dorsal spine of right valve is placed below of its dorsal margin Euconchoecia species 1

12b. Postero-dorsal spine and dorsal margin of right valve form one straight line. E. aculeata 


\section{MORPHOLOGY AND SYSTEMATICS OF EUCONCHOECIA}

13a. Rostrum on right and left valves is aproximately equal in length, postero-dorsal spine on right valve is placed below its dorsal margin. Euconchoecia species 3

13b Rostrum on left valve is considerably longer than on right valve, postero-dorsal spine and dorsal margin of right valve form one straight line..... 14.

14a. Length of shell $<1.4 \mathrm{~mm}$, postero-dorsal spine and dorsal margin of right valve aligned. E. elongata 14b. Length of shell $>1.5 \mathrm{~mm}$, postero-dorsal spine on right valve below of dorsal margin

Euconchoecia species 5

\section{Acknowledgments}

The author is greatly indebted to Dr. M.V. Angel (Southampton Oceanography Centre, Great Britain) for improvement of structure and language of manuscript. Also I appreciate the comments and criticism of the manuscript by reviewers. Beside I wish to thank G.G. Stovbun (A.V. Zhirmunsky Institute of Marine Biology, Far East Branch of Russian Academy of Science, Vladivostok, Russia) for technical preparation of manuscript.

\section{Literature cited}

Angel, M. V. 1979. Studies on Atlantic halocyprid ostracods: their vertical distributions and community in the central gyre region along latitude $30^{\circ} \mathrm{N}$ from off Africa to Bermuda. Progress of Oceanography, 8, 3-124.

Angel, M. V., Fasham M. J. R. 1975. Analysis of the vertical and geographic distribution of the abundant species of planktonic ostracods in the North-East Atlantic. Journal of the Marine Biological Association of the United Kingdom, 55, 709-737.

Angel, M.V., Graves, C.D. 2013. Bathyconchoeciinae, a new subfamily of deep oceanic planktonic halocyprid Ostracod (Myodocopa, Ostracoda). Zootaxa, 3630 (2), 243-269.

Bainbridge, V. 1972. The zooplankton of the Gulf of Guinea. Bulletin Marine Ecology, 8, 61-92.

Baker, J. H., Jones, T. L., and Salinas J. 1977. Occurrence of Euconchoecia chierchiae Müller, 1890 (Ostracoda, Halocyprididae) in Cedar Bayou, Chambers Country, Texas. Chesapeake Science, 18(44), 394.

Barney, R. W. 1921. Crustacea, V: Ostracoda: British Antarctica ("Terra Nova") Expedition, 1910. Natural History Reports of the terra Nova Expedition, 3(7), 175-190.

Brady, G. S. 1902. On new or imperfectly-known Ostracoda, chiefly from a collection in the Zoological Museum, Copenhagen. Transactions of the Zoological Society of London, 16(4), 179-210.

Chavtur, V. G. 1976. [Fauna of pelagic ostracods of the Far-Eastern Seas. In: Coastal communities of the Far-Eastern Seas.]. Institute Biologii Morija AN SSSR, Vladivostok, 6, 99-109 [In Russian].

Chavtur, V. G. 1977. Fauna of pelagic ostracods of the Halocypridae family in the northwestern part of the Pacific Ocean. Sovetskye Trudy Marine Biology, 3(3), 18-26.

Chavtur, V. G. 1991. [History-bibliographic review and analysis of study recent ostracod-myodocops of the Oceans World.]. Vladivostok, Dalnevostochnoe Otdelenie Akademii Nauk SSSR, 2(3), 136 pp. [In Russian].

Chavtur, V. G. 1992. [Composition, structure and distribution benthic and pelagic ostracods of the superorder Myodocopa of temperate and cold waters of the Northern Hemisphere.]. Institute Biologii Morija , Dalnevostochnoe Otdelenie Akademii Nauk, Vladivostok, 155 pp., 30 figs., 96 bibl. nam. Deponent VINITI, N3016- VD 2, 20. 10. 92. [In Russian]. 


\section{VLADIMIR G. CHAVTUR}

Chen, Q., Yin, J., Zhang, G. 1983. Studies on pelagic ostracods in the central and northern parts of the South China Sea. Contributions on Marine Biological Research of the South China Sea, 3(1), 82-132.

Chen, R. - X. 1978. Ostracoda in the coastal water of the East China Sea. Journal of Oceanology. (Peoples Republic of China), 8, 39-52 (quoted from Tseng, 1980).

Chen, R. - X. 1982. The distribution on planktonic Ostracoda along the western coast of Taiwan Straits. Acta Oceanologica Sinica, 1(2), 289-298.

Chen, R., Lin, J. 1984. A new species of Euconchoecia from the East China Sea. Acta Oceanologica Sinica, 5 (sup.): 859-861 [In Chinese].

Chen, R., Lin, J. 1985. A new species of Euconchoecia from the East China Sea. Acta Oceanologica Sinica, 4(1), 131-124.

Chen, R., Lin, J. 1995. Pelagic Ostracoda in China Seas. China Ocean, 134 pp. [In Chinese].

Cleve, P. T. 1900. The seasonal distribution of Atlantic plankton organisms. Ostacoda. Götenborg, 38-40.

Cleve, P. T. 1904. Report on plankton collected by Mr. Thorild Wulff during a voyage to and from Bombay. Archive för Zoolgiska Stockholm, 1, 329-398.

Cleve, P. T. 1905. The plankton of the South African Seas. III. Halocyprididae. Marine Investigations in South Africa. Cape Town, 4, 129-132.

Dakin,W. J., Colefax, A. N. 1940. The plankton of the Australian coastal waters off New South Wales. Publication of the University of Sydney, Department of Zoology, Monograph, 1, $215 \mathrm{pp}$.

Darby, D. S. 1965. Ecology and taxonomy of Ostracoda in the vicinity of Sapelo Islands, Georgia. Ann Arbor. Michigan University of Michigan, 1-76.

Deevey, G. B. 1952. Quantity and composition of the zooplankton of Block Island Sound, 1949. Bulletin of Bingham Oceanography, Coll., 13(3), 120-164.

Deevey, G. B. 1960. The zooplankton of the surface waters of the Delaware Bay region. Bulletin of Bingham Oceanography, Collect., 17(2), 5-53.

Deevey, G. B., 1968. Pelagic ostracods of the Sargasso Sea off Bermuda. Peabody Museum of Natural History Yale University. 26, $125 \mathrm{pp}$.

Deevey, G. B. 1970. Pelagic ostracods (Myodocopa, Halocyprididae) from the North Atlantic off Barbados. Proceedings of the Biological Society of Washington, 82 (62), 799-824.

Deevey, G. B. 1971. The annual cycle in quantity and composition of the zooplankton of the Sargasso Sea off Bermuda. I. The upper $500 \mathrm{~m}$. Limnology and Oceanography, 16 (2), 219-240.

Deevey, G. B. 1978. The planktonic ostracods of the Cariaco Trench and adjacent waters. Proceedings Biological Society of Washington, 91(1), 52-73.

Deevey, G. B. 1982. Planktonic ostracods of the north Atlantic off Barbados. Bulletin of Marine Science 32 (2), 467-488.

Deevey, G. B., Brooks, A. L. 1980. The planktonic ostracods of the Sargasso Sea off Bermuda: species composition and vertical and seasonal distribution between the surface and $2000 \mathrm{~m}$. Bulletin of the Florida State Museum Biological Science, 26 (2), 37-124.

Drapun, I. E. 1983. [Pelagic ostracods from the south-west sector of the South Atlantic subtropical circulation]. Ecologia morja, 14, 33-37 [In Russian].

Falavigna, da R. C. E. 1983. Distribution of Euconchoecia chierchiae G. W. Müller (Crustacea, Ostracoda) off Santos, Brazil. Bolm de Zoologia, Universidade de São Paulo, 6, 53-61.

George, J., 1969. A preliminary report on the distribution and abundance of planktonic ostracods in the Indian Ocean. Bulletin of the National Institute of Sciences of India, 38(2), 641-648.

George, J., Nai, V. P. 1980. Planktonic ostracods of the Northern Indian Ocean. Mahasagar: Bulletin of the National Institute of Oceanography, 13(1), 29-44.

Gonzales, L. C., Breman, E. 1982. Distribution of planktonic Ostacoda in the surface waters of the Bonaire Basin and adjacent seas. Crustaceana, 42(2), 201-211. 


\section{MORPHOLOGY AND SYSTEMATICS OF EUCONCHOECIA}

Graves, C.D. Redescription of Euconchoecia chierchiae Müller, 1890 and Euconchoecia aculeate (Scott, 1894) (Halocyprididae, Ostracoda) from the Atlantic, and description of two novel species of Euconchoecia Müller, 1890, fhjv the Gulf of Oman. Journal of Natural History, 45, 1937-1981.

Hanai, T., Ikeya, N., Yajima, M. 1980. Checklist of Ostacoda from Southeast Asia. Bulletin of the University Museum, Univesity of Tokyo, 17, 236 pp.

Hartmann, G., 1959. Zur kentnis der lotischen lebehsbereiche der pazifischen küste von El Salvador unter besonderer Berücksichtigung seiner Ostacoden fauna. Kiel. Meeresforsch, 15 (2), 187-241.

Hopkins, T. L., 1966. The plankton of the St. Andrew. Bay system, Florida. Publication Institute of Marine Science, University of Texas, 11, 12-14.

Kornicker, L. S., Iliffe, T. M. 1989. New Ostacoda (Halocyprida: Thaumatocyprididae and Halocyprididae) from anchialine caves in the Bahamas, Palau, and Mexico. Smithsomian Contribution Zoolology, 470, 47 pp.

Leveau, M. 1967. Ostracodes pélagiques du sud-ouest de l'ocean Indien (région de Tuléar). Recueil des travaux de la Station marine Endoume, Marseille Fascicule hors série supplement, 6, 63-70.

Leveau, M. 1969. Ostracodes pélagiques recuillis lors de la $3^{\circ}$ campagne de l'aviso "Commandant Robert Giraud". Recueil des travaux de la Station marine Endoume, Marseille Fascicule hors série supplement, 8, 123-142.

Leveau, M., Szekielda K. H. 1968. Situation hydrologique et distribution du zooplankton dans le N. W. de la mer d'Arabie. Sarsia, 34, 285-298.

McKenzie, K. G., Milne, P. W., Bryen, C., Freeman, K. 1979. Distribution of marine planktonic and benthic Ostracoda in Northern Australian waters and some correlated environmental factors. In Kristic N. (ed.) Proceedings of the 7th Int. Symposium on Ostracodes. Beograd, Vol 1. pp 233-236.

Moguilevsky, A., Angel M. V. 1975. Halocyprid ostracods in Atlantic neuston. Marine Biology, 32, 295-302.

Motoda, S., Azechi K., Narumo T., Sawad T., Seki C., 1972. Preliminary notes on the distribution of some zooplankton groups in the sea south of Java Island. Journal of the Marine Biological Association, India, $14,109-114$.

Müller, G. W. 1890. Ueber Halocypriden. Zoologische Jahrbuecher, 5, 253-278.

Müller, G. W. 1906. Ostacoda. Wissenschaftlike Ergebnisse der Deutsche. Tiefsee-Expedition auf dem Dampfer "Valdivia", 8, 154 pp.

Müller, G. W. 1908. Die Ostacoden Der Deutschen Südpolar-Expedition 1901-1903. Südpolar-Expedion 1901-1903, Zoologie, Berlin, 10(2), 53-184.

Müller, G. W. 1912. Ostracoden. Das Tirreich. Berlin. 31, 434 pp.

Okera, W. 1974. The zooplankton of the inshore water of Dar es Salaam (Tanzania, E. A. Africa) with observations on reactions to artificial light. Marine Biology 26(1), 13-25.

Poulsen, E. M. 1969a. Ostacoda - Myodocopa. Pt III A. Halocypriformes - Thaumatocypridae and Halocypridae. Dana-Report, 5, 100 pp.

Poulsen, E. M. 1969b. Ostacoda - Myodocopa from the eastern tropical Atlantic. Videnskabelide Meddelelser fra Dansk naturhistorik Forening, Kjobenhavn, 132, 129-197.

Scott, T. 1894. Report on Entomostraca from the Gulf of Guinea, collected by John Rattray. Transaction of the Linneus Society of London, series 2 (Zoology), 6(1), $161 \mathrm{pp}$.

Scott, T. 1912. The Entomostraca of the Scottish National Antarctic Expedition, 1902-1904. Transactions of the Royal Society of Edinburgh, 48(3), 521-600.

Seguin, G. 1966. Contribution à l'étude de la biologie du plancton de la baie de Dakar (Sénegal). Bulletin Institut France Africa Noire, 28,1-90.

Skogsberg, T. 1920. Studies on marine ostracods. Pt. 1 (Cypridinids, Halocypridinids and Polycopids). Zoologiska Bidrag från Uppsala, 784 pp.

Tseng, W. Y. 1969. Euconchoecia (Ostracoda) from Taiwan Straits. Laboratory of Fishery Biology Report, Taiwan, 19, 1-26. 


\section{VLADIMIR G. CHAVTUR}

Tseng W. Y. 1970a. The zooplankton community in the surface waters of Taiwan Straits. In, Sugawara K. (ed.). The Kuroshio: Proceedings of the 2nd CSK Symposium, Tokyo, 261-272.

Tseng W. Y. 1970b. Occurrence of ostracods in the neighbouring seas of Taiwan. In, Sugawara K (ed.). The Kuroshio: Proceedings of the 2nd CSK Symposium, Tokyo, 285-295.

Tseng. W. Y. 1970c. A preliminary report on Cypridinids (Ostracoda) from Taiwan Straits. In, Marr J. C. (ed.). The Kuroshio: Symposium on Japanese Current, Honolulu, East-West Center Press, 339-346.

Tseng W. Y. 1975. Biology of the pelagic ostracod, Euconchoecia elongata. Laboratory of Fishery Biology Reptort, Taiwan, 27, 1-183 (quoted from Tseng, 1980).

Tseng W. Y. 1976. Development of the pelagic ostracod, Euconchoecia elongata Müller, 1906. Abhandlungen Verhaltens naturwissen-schaftlisser Verein Hamburg, (Neue Folge), 18/19 (suplement), 201-213.

Tseng W. Y. 1980. The Pelagic Ostracoda of Hong Kong. In, Morton B. C. and Tseng C. K. (ed.). The marine flora and fauna of Hong Kong and Southern China: Proceedings of the First Institute of Marine Biology Workshop, Hong Kong, Hong Kong University Press: 401-430.

Vavra V. 1906. Die ostracoden (Halocypriden und Cypridiniden) der Plankton-Expedition. Ergebniss der Plankton-Expedition der Humboldt-Stiftung, Kiel, Leipzig, 2, 76 pp.

Vinogradov M. E. 1968. Vertical distribution of the oceanic zooplankton. Publishing House "Nauka": 320 pp. [In Russian]. Translated by the Israel Program of Scientific Translation: Jerusalem, 1970, 339 pp. 


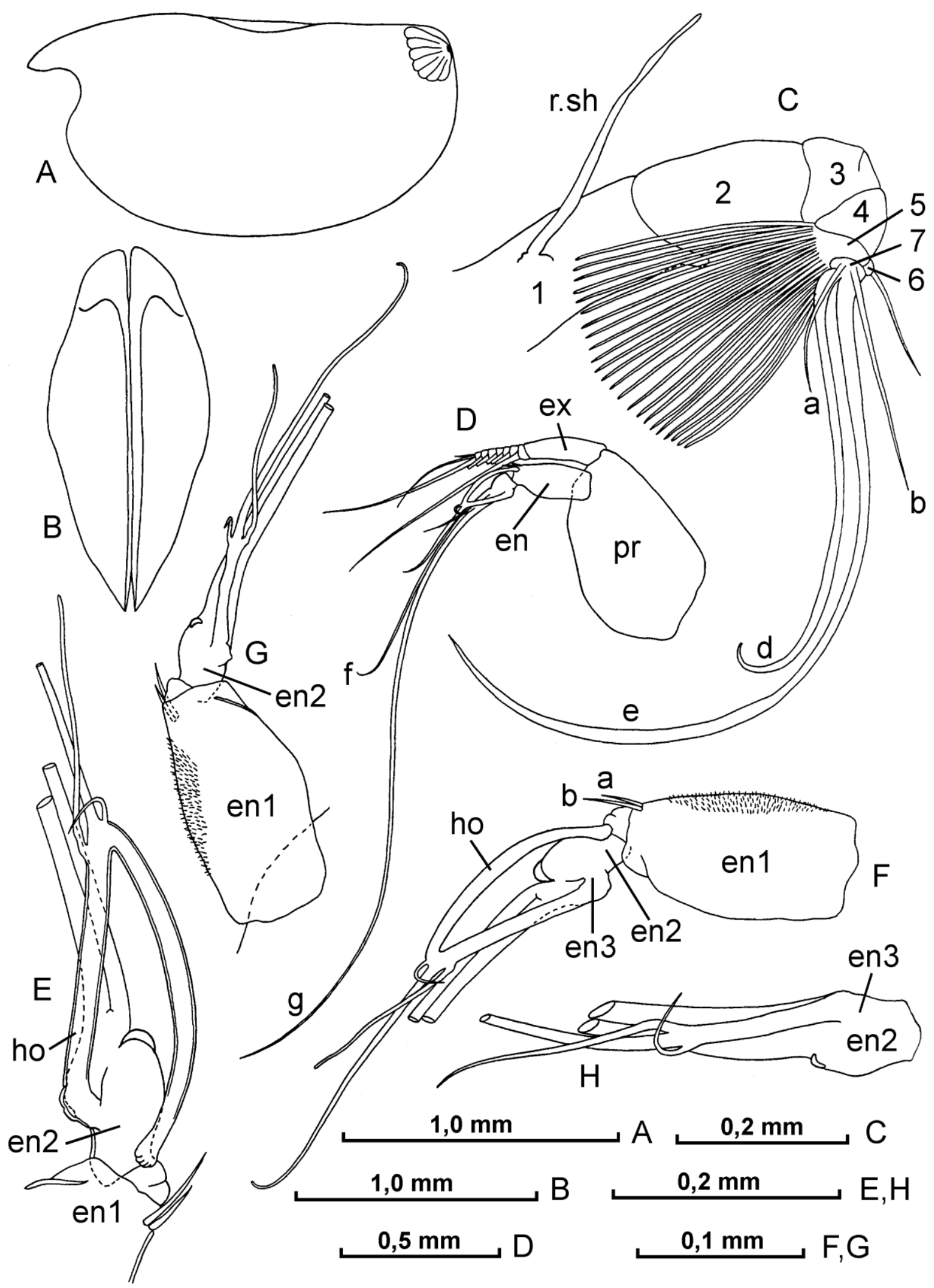

Figure 1. Euconchoecia pacifica (male: A-F, H - N2773 and G - N2774). A - left valve of shell, B - shell in ventral view, $\mathrm{C}$ - frontal organ and first antenna, D - second antenna, E and F - right endopodite of second antenna, $\mathrm{G}$ and $\mathrm{H}$ - left endopodite of second antenna. 


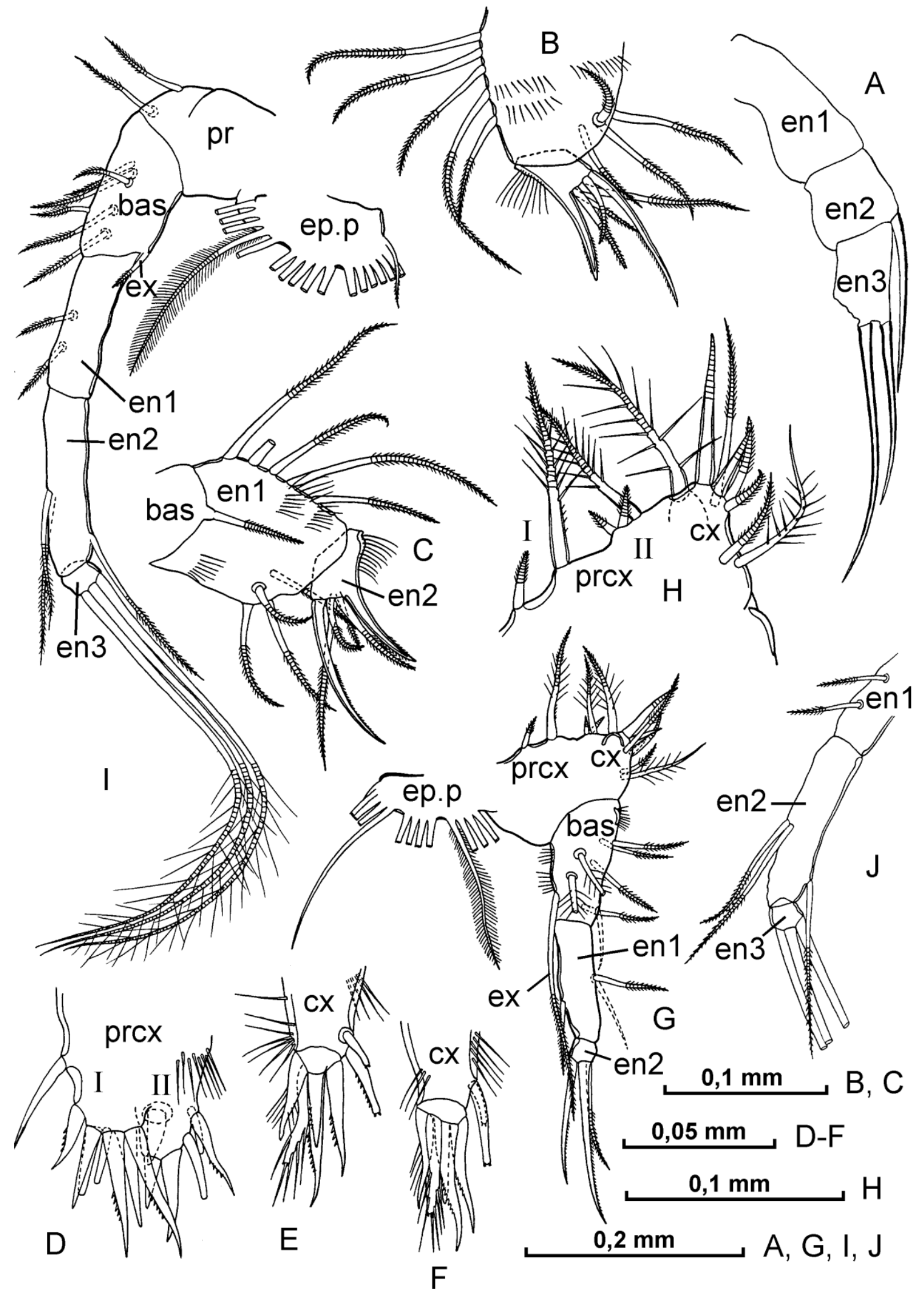

Figure 2. Euconchoecia pacifica (male - N2774). A - endopodite of mandible, B and C - maxilla, D-F precoxal and coxal endites of maxilla, $\mathrm{G}$ and $\mathrm{H}$ - fifth limb and its proximal part, I and $\mathrm{J}$ - sixth limb and its distal part. 


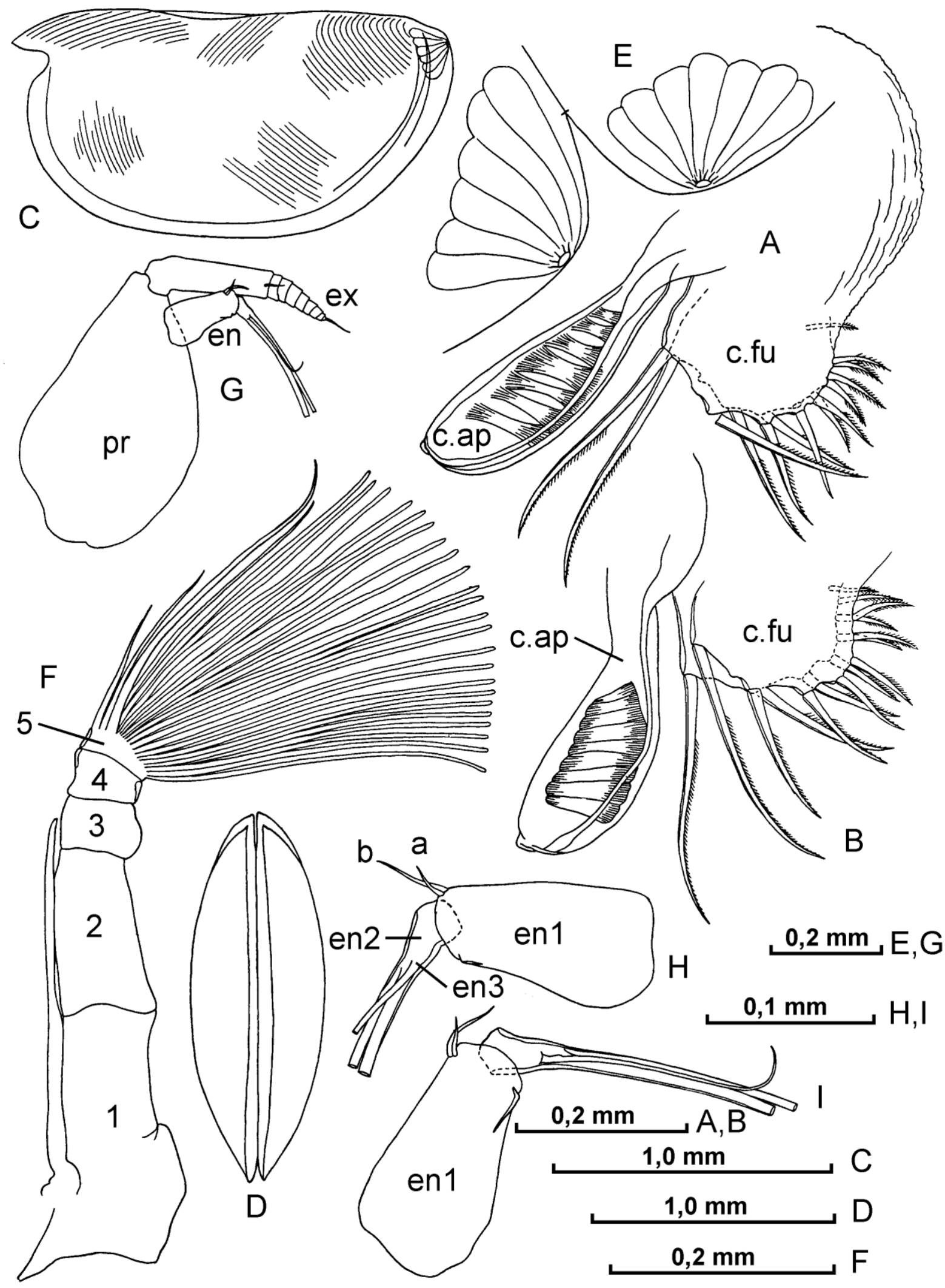

Figure 3. Euconchoecia pacifica (male: A - N2774 and B - N2773; female: C-F - N2772 and G-I - N2776) A and B - copulatory appendage and caudal furca, C - left valve of shell, D - shell in ventral view, E postero-dorsal angles of shell, F - frontal organ and first antenna, G - second antenna, H and I - endopodite of second antenna. 


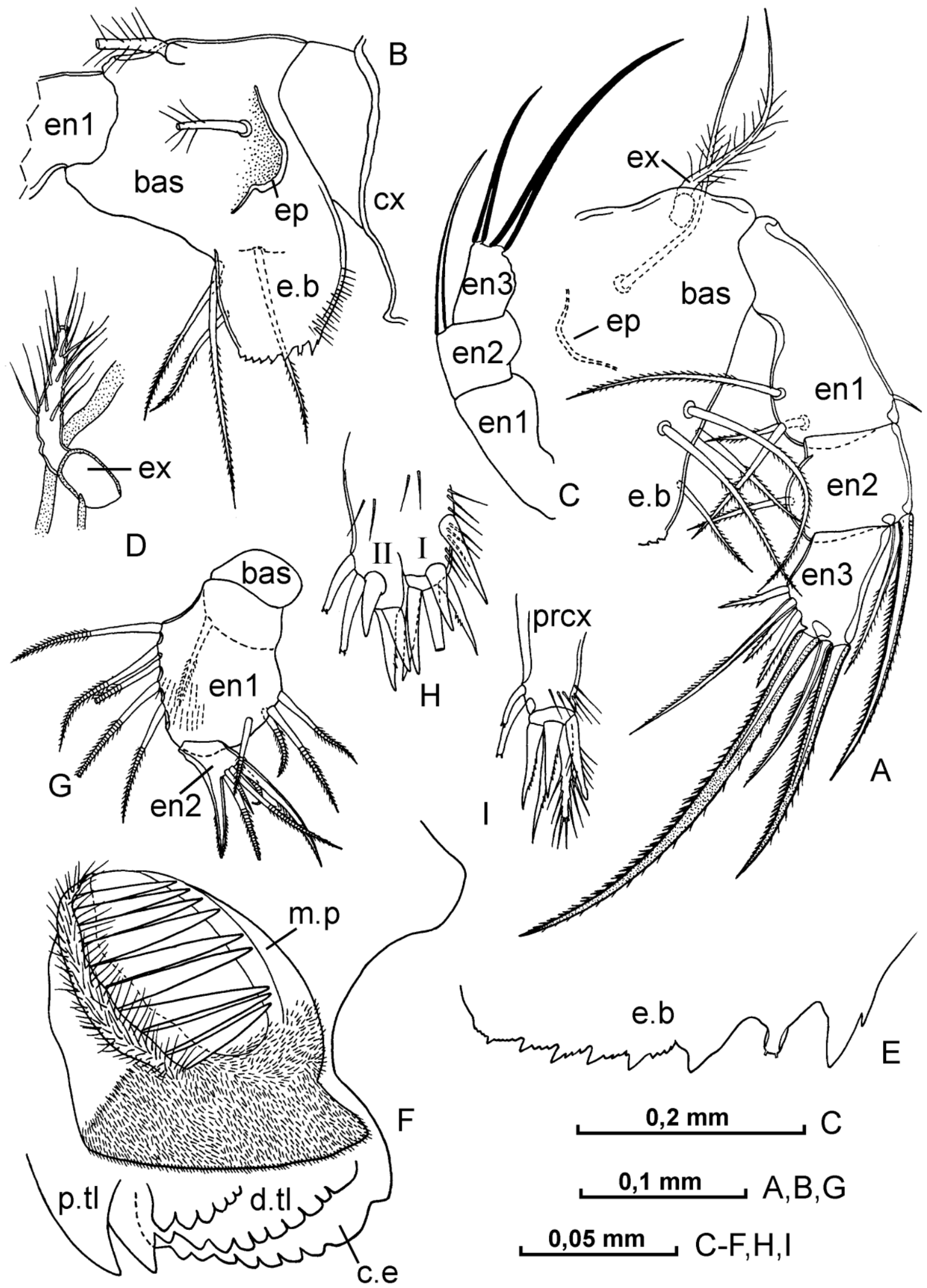

Figure 4. Euconchoecia pacifica (female: A, C, G-I - N2776 and B, D-F - N2772). A - mandible, B - basale and exopodite of mandible, $\mathrm{C}$ and $\mathrm{D}$ - endopodite and exopodite of mandible, $\mathrm{E}$ - basal endite of mandible, $\mathrm{F}$ tooth edge, distal and proximal tooth rows and masticatory pad on coxale of mandible, G - maxilla, H and I precoxal and coxal endites of maxilla. 


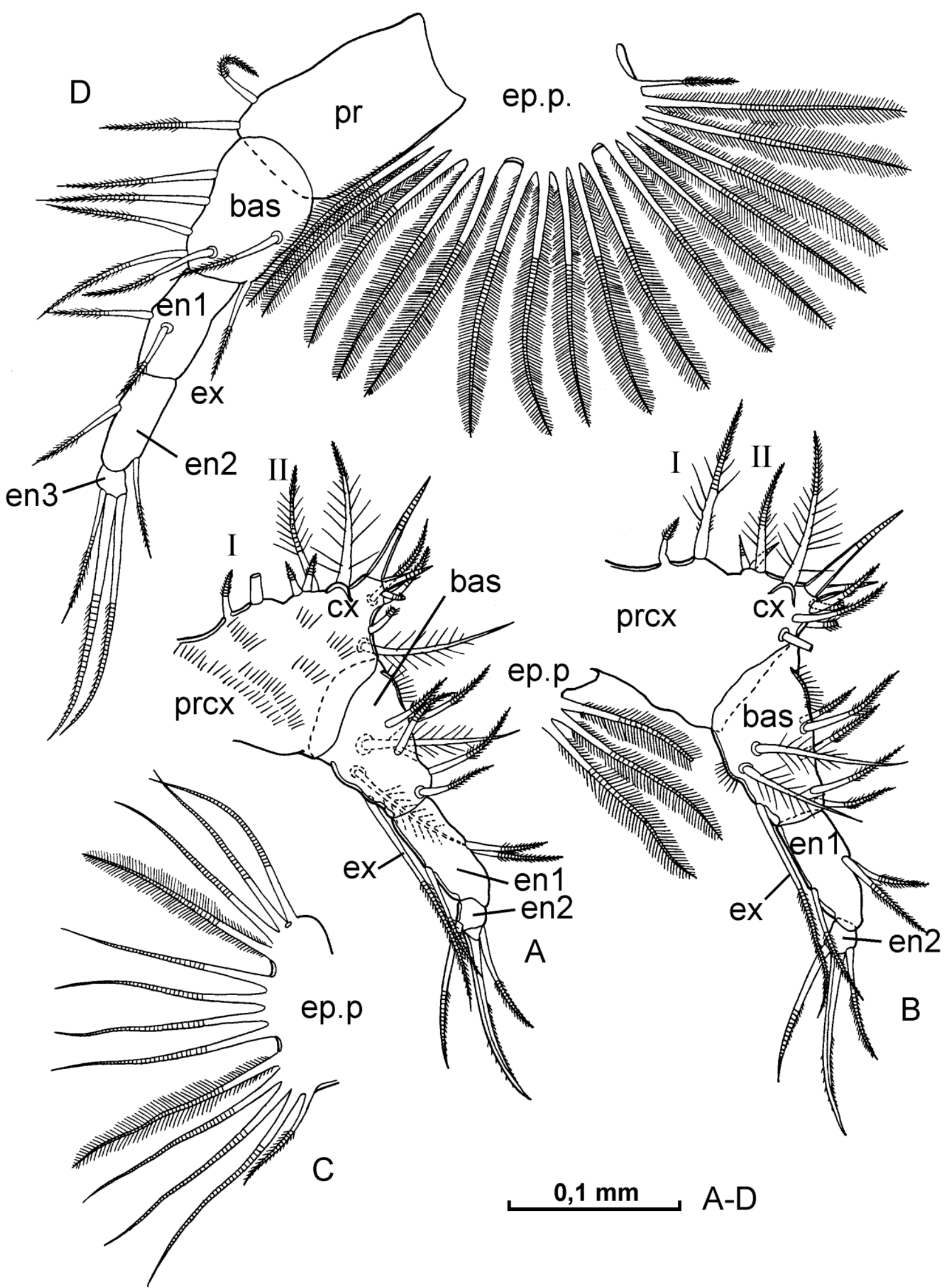

Figure 5. Euconchoecia pacifica (female- N2776) A and B - fifth limb, C - epipodite of 5th limb, D - sixth limb. 


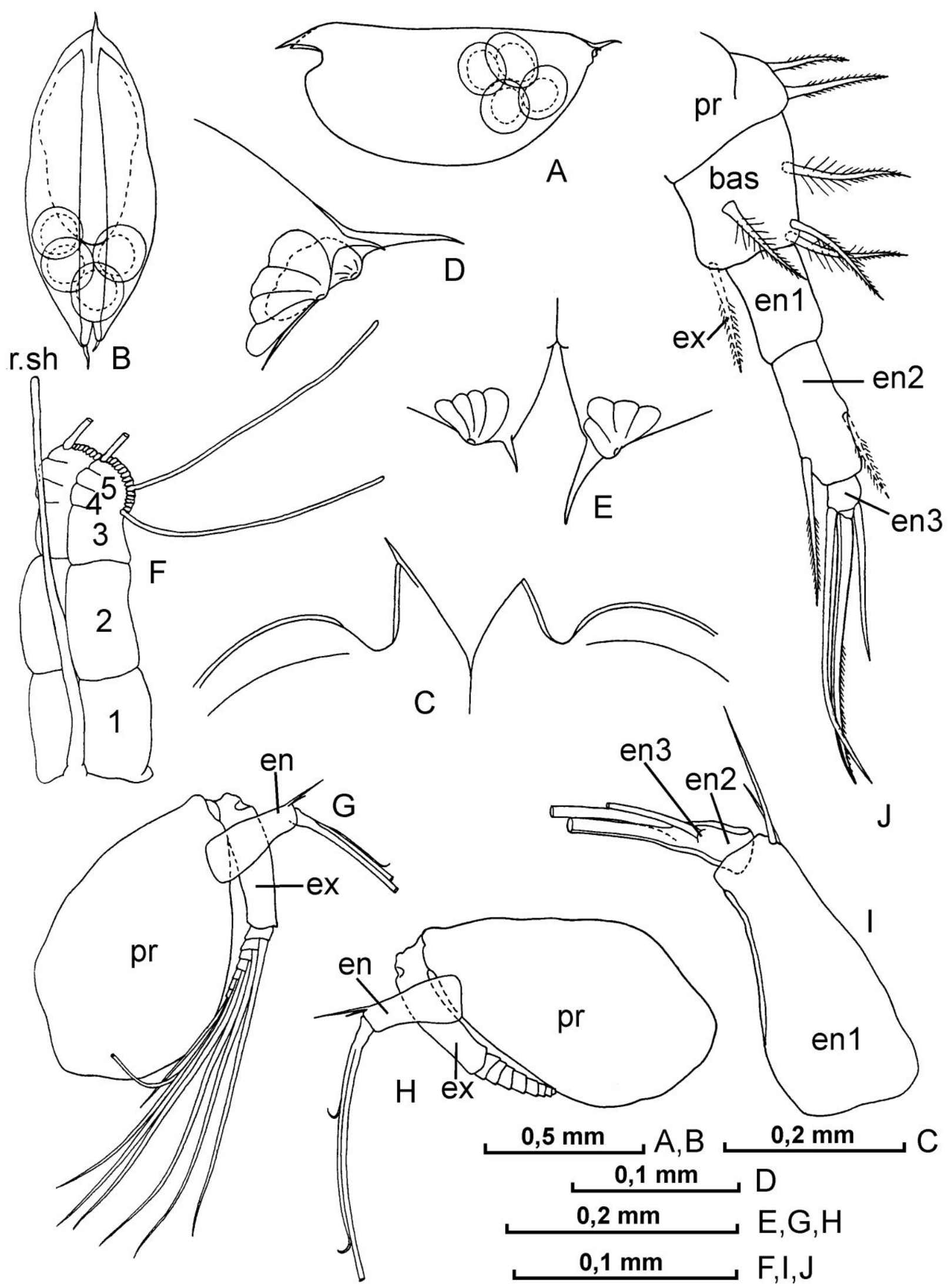

Figure 6. Euconchoecia species 3 (female - N2779) A - left valve of shell, B - shell in ventral view, C antero-dorsal part of shell in ventral view, D and E - postero-dorsal part of shell in lateral and ventral views, $\mathrm{F}$ - frontal organ and first antenna, G and H - second antenna, I - endopodite of second antenna, J - sixth limb. 


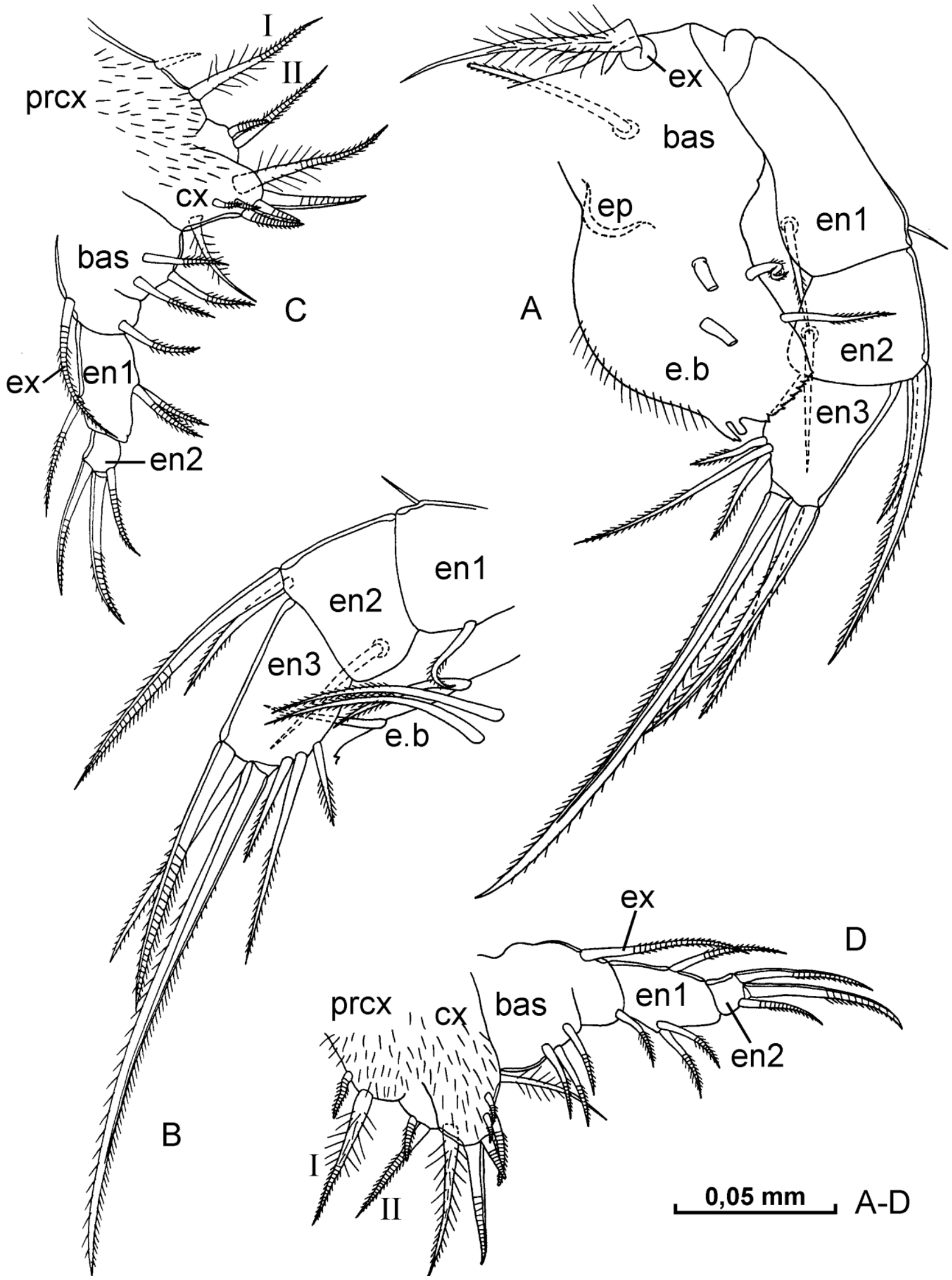

Figure 7. Euconchoecia species 3 (female - N2779) A and B - mandible, C and D - fifth limb. 


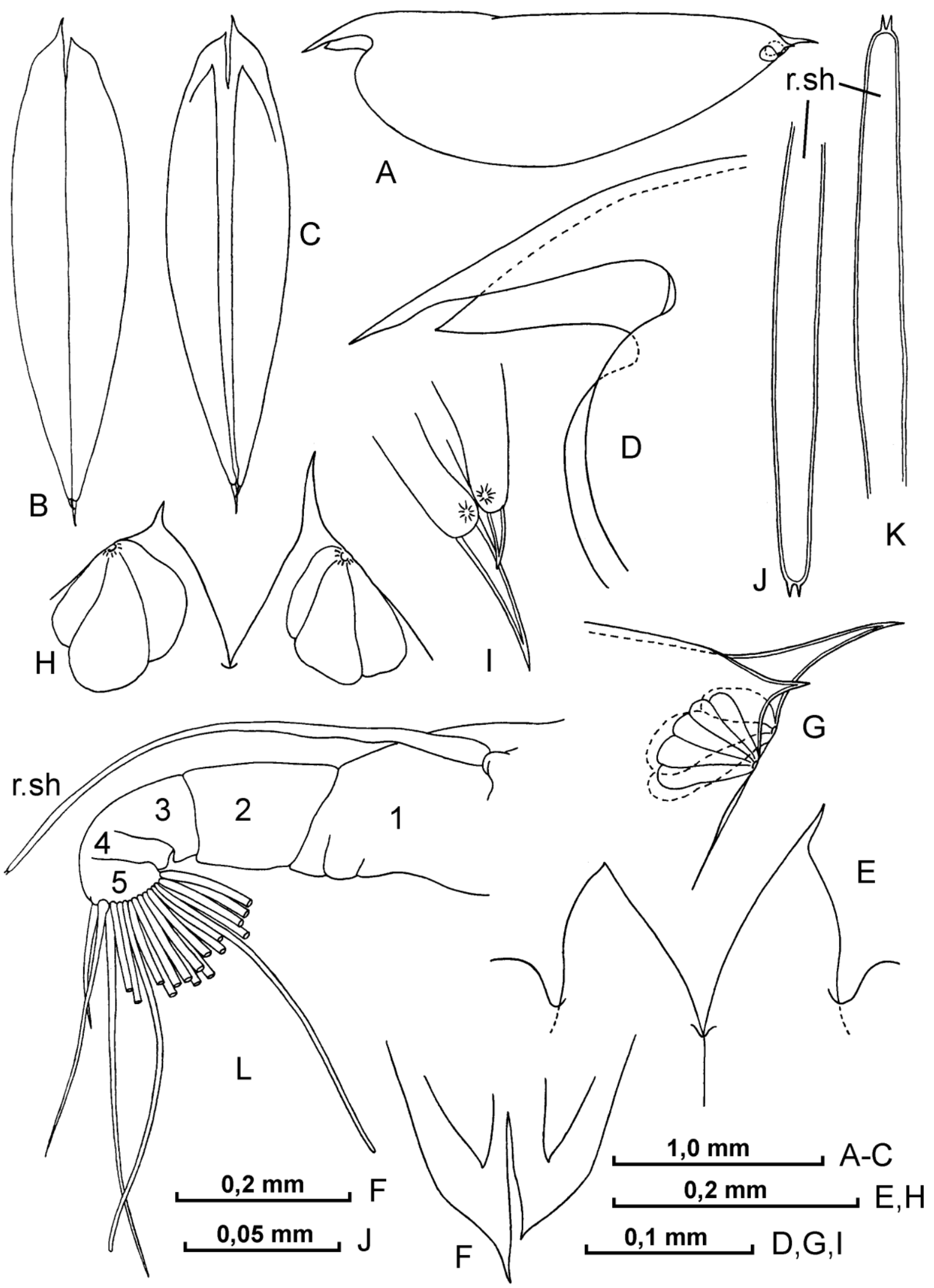

Figure 8. Euconchoecia species 6 (female: A-I, K - N2777 and J, L - N2778) A, B and C - shell in lateral, dorsal and ventral views, D - rostrum of shell in lateral view, E and F - rostrum in ventral view, G postero-dorsal part of shell in lateral view, $\mathrm{H}$ and $\mathrm{I}$ - postero-dorsal part in ventral view, $\mathrm{J}$ and $\mathrm{K}$ - distal part of frontal organ, L - frontal organ and first antenna. 


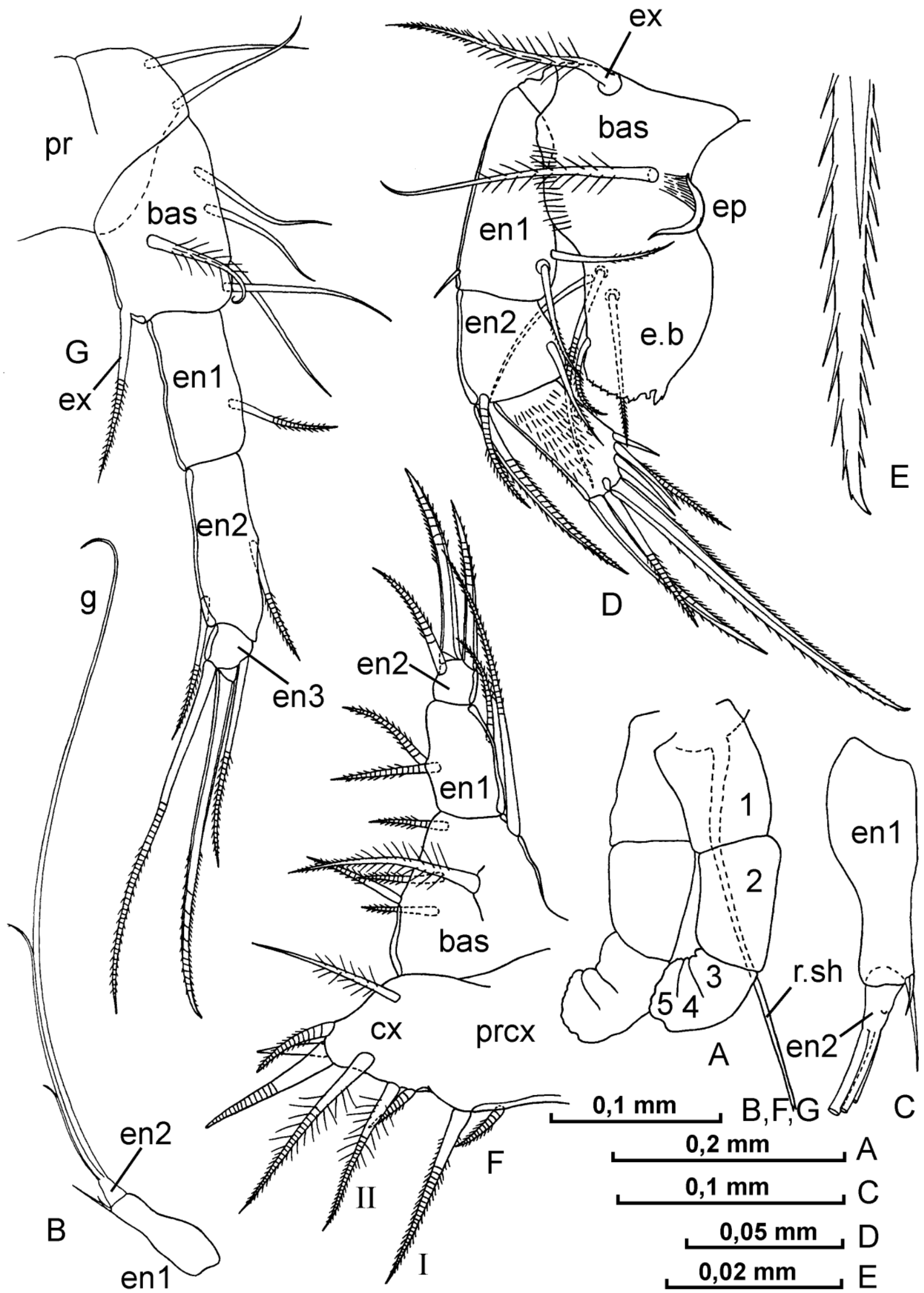

Figure 9. Euconchoecia species 6 (female: A - N2778 and B-G - N2777). A - frontal organ and first antenna, B and C - endopodite of second antenna; D - mandible, E - distal part of main claw on mandible, F fifth limb, G - sixth limb. 